\title{
Never-Ending Story? Political Dynamics, Legislative Uncertainties, and Practical Drawbacks of the 'New' Pact on Migration and Asylum
}

\section{Daniel Thym"}

No one would maintain that European asylum policy is in a healthy state and that things should, on the whole, continue as they are. Core aspects of asylum policy resemble a stuttering-if not outright dysfunctional-engine more than a politically sustainable, practically functioning, and normatively balanced approach. The signs of malfunctioning and occasional failure are palpable. Think of the situation at the external borders, regular disputes about secondary movements, and the miserable reception conditions for asylum seekers in some hotspots. That is why the Commission had proposed legislative reform back in 2016, which the institutions failed to agree upon (with the exception of Frontex). The 'new' Pact on Migration and Asylum, proposed by the Commission in September 2020 with much fanfare, was meant to show a way out of the political impasse.

Contributions to this edited volume set out to explore the contents and the implications of the Commission's policy proposals in light of developments in the year following their presentation. In doing so, they go beyond the legislative proposals that are at the centre of the political and academic debate. Indeed, the 'Pact on Migration and Asylum' transcends the legislative component-in the same way as the notion of an European 'asylum policy' is generally understood to be broader than the legislative instruments that make up the Common European Asylum System (CEAS). Asylum policy embraces cooperation with third states, the impact of entry and border controls on asylum seekers, return of unsuccessful applicants, and the integration of beneficiaries of international protection. ${ }^{1}$

* Professor of Public, European and International Law and managing Director of the Research Centre Immigration \& Asylum Law at the University of Konstanz, Germany.

1 See the distinction between broader 'asylum policy' and the legislative instruments building the CEAS in the seminal European Council, Presidency Conclusions of the Meeting on 15 and 16 October 1999 in Tampere, paras 10-27. 
Rereading the 28 pages of the political communication introducing the 'new' Pact in the autumn of 2020, one realises that only half of them concerned new legislation. The remainder focused on other aspects: cooperation with third states; databases and more powers for Frontex; measures against smuggling; legal pathways for refugees and economic migrants; and Schengen evaluation. ${ }^{2}$ These other elements are proceeding besides asylum legislation, many of them with quite some success. Cooperation with third states is one of the most dynamic-and controversial-elements of asylum policy. One year after the presentation of the Pact, the Commission took stock and was optimistic that the EU would be able to reinforce and broaden existing cooperation frameworks. ${ }^{3}$

\section{Overarching Enquiries}

Three overarching questions define an overall assessment of the reform package and the state of play one year later. Firstly, one is bound to notice that political discussions on the legislative proposals are in a dire state (while cooperation with third states, in particular, develops dynamically). Will the legislative proposals have the same fate as the reform package that had been presented by the Commission in 2016? This introductory contribution will describe the relevant political factors. Nevertheless, we should be careful not to discard the debate as irrelevant even if the institutions failed to agree on new legislation. Contributions to this volume will shed light on core aspects of asylum policy, which retain their practical, political, and normative relevance irrespective of the adoption of new legislation. In that respect, an analysis of the Pact presents a specific angle to analyse core challenges of asylum policy at this juncture.

Secondly, anyone reading the newspaper realises that the law is not enough, as the situation at the external borders exemplifies: insufficient reception conditions on the Greek islands; the notorious failure of the takeback procedure under the Dublin Regulation; and reports about pushbacks by several countries. For our purposes, these examples illustrate that legislative reform is a necessary but ultimately insufficient condition for a functioning asylum system. We need to ensure that the law in the books is

2 See Commission, 'Communication on a New Pact on Migration and Asylum' $\operatorname{COM}(2020) 609$ of 23 September 2020.

3 See Commission, 'Communication on the Report on Migration and Asylum' $\operatorname{COM}(2021) 590$ of 29 September 2021, 15-22. 
being applied in practice. It is not enough to agree on a Directive and to assume that national authorities and domestic courts will ensure effective implementation on the ground. A common question contributions to this volume will have to answer is whether the reform proposals are capable of delivering on the ground what they promise on paper.

Thirdly, the Commission was eager to publicise the novelty factor of the 'new' Pact. The accompanying press release self-consciously proclaimed a 'fresh start' and conceded willingly that ' $[t]$ he current system no longer works' ${ }^{4}$ Many contributions will demonstrate that the nitty-gritty of the different proposals hardly justifies the self-conscious discursive framing of originality. Digging into the more than 300 pages, one is bound to discover rules that contradict the label of a 'fresh start'. Once you take off the wrapping paper, the status quo ante reappears in important respectsnot only with regard to the Dublin III Regulation, which the Commission proposes to repeal on paper, even though many provisions remain intact.

\section{European Realpolitik: Respecting 'Red Lines'}

Commissioner Johansson famously predicted upon presenting the Pact: 'My guess is that I will have zero Member States saying it's a perfect proposal... But I do hope that I'll also have 27 Member States saying it's a balanced approach and let's work on this.' ${ }^{5}$ So it happened. All governments agreed to start negotiating, which may be a small success in itself given that some Member States could possibly have rejected working on the proposal outright. One reason why they agreed to negotiate was the Commission's decision to respect the red lines of national governments and to make a deliberate effort to balance countervailing interests.

This brings us right to the heart of the political disputes. It is widely known that the Visegrád countries have made crystal clear that they will not sign up for mandatory relocation in the form of 'sharing people'. At the same time, we should be careful not to blame solely on the Visegrád countries. One hears repeatedly from people involved in the negotiations

4 Commission, 'A Fresh Start on Migration' (Press Release IP/20/1706, 23 September 2020) <https://ec.europa.eu/commission/presscorner/detail/en/ip_20_1706> accessed 15 December 2021.

5 See Alexandra Brzozowski, 'EU's New Migration Pact to Request "Mandatory Solidarity" from Member States' (EurActiv.com, 23 September 2020) <www.euract iv.com/section/justice-home-affairs/news/eus-new-migration-pact-to-request-manda tory-solidarity-from-member-states> accessed 15 December 2021. 
that other Member States, which do not receive many asylum seekers at present, hide behind Mr Orbán and others. They might be willing to compromise, including on solidarity by means of 'sharing people', but there is little appetite for widescale relocation in capitals across Europe. The Commission accepted that extensive relocation was not a realistic option, in particular for asylum seekers with little statistical chance of receiving a positive decision. ${ }^{6}$ Much followed from this starting point.

Acknowledging that extensive relocation would not happen put the spotlight on the external borders. If you cannot relocate substantial numbers of asylum seekers, you must deal with them in the country of first arrival. We shall see that the infamous first entry rule, according to which countries at the external borders are responsible for asylum applications under the Dublin system, was here to stay even though it may be narrowed somewhat (for instance for search and rescue). Border procedures are an attempt to set up fair and effective procedures, although the Commission was probably aware that they would be extremely challenging to implement. Yet, she had little realistic alternatives...

Note that the continuation of the first entry rule almost inevitably entailed that the transfer of jurisdiction in case of secondary movements would similarly persist. Conservative German politicians reacted angrily to this element, which-like the continuation of the first entry rulefell back behind the state of play of the negotiations on the Dublin IV Regulation. Asserting that the Pact would 'strik[e] a new balance between responsibility and solidarity' ${ }^{7}$ was correct insofar as the proposal embraced new elements (such as 'return sponsorship'). However, it was a public relations stunt when it came to the heart of the political dispute about how to balance support for 'frontline' Member States (solidarity) with respect for European rules and the prevention of secondary movements (responsibility).

That is why I called the Pact an exercise in 'European Realpolitik' in a blogpost a few days after its presentation. ${ }^{8}$ Notwithstanding the rhetoric emphasis on 'solidarity', 'responsibility', or a 'fresh start', the reform pack-

6 Remember that even the Relocation Decisions (EU) 2015/1523 and (EU) 2015/1601 applied to nationals of countries, who usually receive international protection; if we look at arrivals in southern Italy or Spain, we realise that few cross this hurdle at present.

7 Commission Press Release (n 4).

8 See Daniel Thym, 'European Realpolitik: Legislative Uncertainties and Operational Pitfalls of the "New" Pact on Migration and Asylum' (EU Immigration and Asylum Law Blog, 28 September 
age was about pragmatism, not principles. It is certainly not 'beautiful' in the sense of an ideal vision of how migration and asylum policy could possibly look like (even though EU politics has traditionally preferred such grand designs). Instead, it is defined by the needs and circumstances of relevant actors, not morals or ideology, in line with the lexical definition of what realpolitik is commonly understood to mean. ${ }^{9}$

The desire to respect the red lines of national governments in the politically sensitive domain of solidarity may be a sign of political pragmatism and practical wisdom. Nevertheless, the proposals will have to be judged not only in light of the prevailing political climate in the early 2020s. Established constitutional and normative principles that define any migration and asylum policy are equally important as a standard of reference and judgment for the policy debate. Human rights and refugee law have to be respected, practical feasibility remains an important yardstick, and the aspiration of solidarity both within the European Union (Article 80 TFEU) and worldwide (Recital 4 Refugee Convention) are equally important for the analyses throughout this volume.

\section{Dead or Alive? Political Stalemate over the Legislative Proposals}

One year after the presentation of the new Pact, Commission President von der Leyen conceded in her State of the Union Address 2021 that 'progress has been painfully slow' while urging the European Parliament and the Council to 'speed up the process'. ${ }^{10}$ To do so would build trust among national governments and the European citizenry that the European Union was capable of successfully managing a crucial contemporary challenge by combining migration control with respect for human rights. ${ }^{11}$ Slowness of the negotiations concerns, as we have seen, the legislative components, not other elements of the overall reform package, such as cooperation with third states.

2020) <https://eumigrationlawblog.eu/european-realpolitik-legislative-uncertainti es-und-operational-pitfalls-of-the-new-pact-on-migration-and-asylum $>$ accessed 15 December 2021.

9 See <https://en.wikipedia.org/wiki/Realpolitik> accessed 15 December 2021.

10 Ursula von der Leyen, 2021 State of the Union Address, 'Strengthening the Soul of our Union' (Speech/21/4701, 15 September 2021).

11 See also Daniel Thym, 'Migrationssteuerung im Einklang mit den Menschenrechten' (2018) 5-6 Zeitschrift für Ausländerrecht 193-200. 
Commissioner Johansson was realistic enough to understand that no one would be happy—and the situation arguably got worse in the months following the presentation of the Pact. To be sure, the institutions diligently started discussing the different proposals. The European Parliament appointed rapporteurs, and draft reports on two core elements, the Amended Proposal for an Asylum Procedures Regulation and the Asylum and Migration Management Regulation, were tabled in October 2021. ${ }^{12}$ Council working parties similarly started collecting the feedback of the Member States. After one year, files with comments of national governments were available (informally, at least), and several Council Presidencies had prepared draft compromise texts on selected instruments. ${ }^{13}$ Nevertheless, adoption was anything but likely in the foreseeable future; it seemed, rather, as if the negotiations on core questions were blocked.

One element, which may help explain the 'painfully slow' progress was the sheer complexity of the documents making up the 'new' Pact on Migration and Asylum. Legislative proposals alone comprise more than 300 pages, and bureaucrats in national interior ministries had to dig deep into the small print to grasp the contents of the various proposals. Moreover, some of the changes are difficult to identify. A telling example is the Dublin III Regulation, which is to be replaced by the Asylum and Migration Management Regulation. It presents itself as a novel undertaking, even though many provisions are continued without major changes. For new instruments, the Commission does not use track change mode; one has to compare the contents of each article individually; their order was altered substantially, thus obscuring the degree of continuity or change. ${ }^{14}$ For asylum procedures and Eurodac, the Commission tabled amended proposals, which have to be read together with the original documents

12 See European Parliament, 'Draft Report on the Proposal for an Asylum and Migration Management Regulation' (Rapporteur: Tomas Tobé), PE698.950v01-00 of 11 October 2021; and European Parliament, 'Draft Report on the Amended Proposal for an Asylum Procedures Regulation' (Rapporteur: Fabienne Keller), PE698.950v01-00 of 13 October 2021; they presented the views of the rapporteurs only, before the input of members of other political groups.

13 See the diverse entries on 'EU: Tracking the Pact' in the news section of Statewatch, which informally publishes many confidential documents $<$ www.statewat ch.org/news $>$ accessed 15 December 2021.

14 See Commission, Proposal for an Asylum and Migration Management Regulation, $\operatorname{COM}(2020) 610$ of 23 September 2020. 
presented in 2016. ${ }^{15}$ Even experts of migration law needed weeks to digest the material.

Discussions during the first months of 2021 witnessed increasing tensions between Mediterranean and Northern countries, which threatened to overshadow the principled opposition of the Visegrád countries (V4). Spain, Italy, Greece, Cyprus, and Malta were particularly outspoken in their principled criticism of core elements of the Commission proposals, insofar as asylum procedures at the external borders are concerned; they even created the label 'MED5' to present themselves as a uniform grouping (even though the interests and positions of governments may vary). ${ }^{16}$ Countries further North quietly abandoned the voluntary relocation of those rescued at sea under the so-called Malta Declaration given the small overall number of asylum applications in Italy; ${ }^{17}$ they also sent a strongly worded letter to Greece, complaining about secondary movements of asylum seekers and beneficiaries of international protection. ${ }^{18}$ Statistics showed that the number of people filing another asylum claim in Germany was higher than the one for new arrivals on the Greek islands during the same period.

For the negotiations, increasing tensions between Mediterranean and Northern countries are toxic for the simple reason that these states sustain the European asylum system: they bear the brunt of responsibilities in terms of border controls, search and rescue, asylum procedures, return, and eventual integration. ${ }^{19}$ If the Northern and Mediterranean countries

15 See Commission, Amended Proposal for an Asylum Procedures Regulation, $\operatorname{COM}(2020) 611$ of 23 September 2020; and Commission, Amended Proposal for a Eurodac Regulation, $\operatorname{COM}(2020) 614$ of 23 September 2020.

16 See Nikolaj Nielsen, 'EU “Front-Line” States Want Clearer Migration Rules' (EU Observer, 26 November 2020) <https://euobserver.com/migration/150196> accessed 15 December 2021; and "Club Med” Countries Show United Front on Migration' (EurActiv.com, 22 March 2021) <www.euractiv.com/section/justice-home-affairs/n ews/club-med-countries-show-united-front-on-migration/> accessed 15 December 2021.

17 On the previous practice, see Simone Penasa and Graziella Romeo, 'Sovereigntybased Arguments and the European Asylum System' (2020) 22 EJML 11, 20-26.

18 See the letter by Germany, France, Belgium, Luxembourg, the Netherlands and Switzerland dated 1 June $2021<$ www.statewatch.org/news/2021/june/whip-greeceinto-shape-so-we-can-resume-migrant-removals-northern-schengen-states-demand > accessed 15 December 2021.

19 See also Ralf Lesser, Ann-Sophie Nienhoff and Nora Schmidt, 'Der "New Pact on Migration and Asylum” Neustart unter deutscher EU-Ratspräsidentschaft zur Reform des Gemeinsamen Europäischen Asylsystems' (2021) 4 Zeitschrift für Ausländerrecht 139, 142. 
fail to compromise, an agreement might be impossible to reach. Remember also that there is a 'silent majority' of countries which, to varying degrees, are reasonably happy with the status quo for the simple reason that few asylum seekers move there at present. Like it or not, most national capitals define their national interest in terms of minimising the number of asylum applications. EU asylum policy may be dysfunctional in many respects, but not all Member States are equally affected by asymmetric migratory patterns.

Then again, politics are the art of the possible (in the words of Otto von Bismarck, Germany's leading chancellor of the $19^{\text {th }}$ century). EU institutions have a track record in endurance and stamina, having overcome a seemingly hopeless political stalemate. In that respect, external factors may have brought Member States closer together. The collapse of the Western-backed government in Afghanistan and the scandalous behaviour of the Belarusian dictator Lukashenko, who used migrants as an instrument to exercise political pressure during $2021,{ }^{20}$ might bring about new dynamics. After all, crises, real or perceived, have been opportunities for reform in Europe before. Countries like Lithuania or Poland realise that anyone can be affected by migratory movements, thus possibly supporting the willingness to compromise, although the outcome of any agreement in such context would be more restrictive than many observers might appreciate. Commission proposals on the instrumentalisation of migration and a reform of the Schengen Borders Code, presented in December 2021, show that the institutions are eager to sustain a dynamic debate. ${ }^{21}$

\section{Breaking the Deadlock through 'Mini-Deals' and Majority-Voting?}

Political negotiations on complex portfolios, such as asylum policy, often pursue a package approach: nothing is agreed until everything is agreed. Even if the institutions succeed in closing the negotiations on individual

20 See 'Belarus plays on the EU's migration concerns' (FT.com, 22 August 2021), $<$ www.ft.com/content/7a036e79-69f9-410b-8faa-89607396afe9> accessed 15 December 2021.

21 See Commission Proposal for a Council Decision on provisional emergency measures for the benefit of Latvia, Lithuania and Poland, $\operatorname{COM}(2021) 752$ of 1 December 2021; Commission Proposal for a Regulation addressing situations of instrumentalisation in the field of migration and asylum, $\operatorname{COM}(2021) 890$ of 14 December 2021; and Commission Proposal for an Amendment of the Schengen Borders Code Regulation (EU) 2016/399, COM(2021) 891 of 14 December 2021. 
chapters, formal adoption of the provisional agreement may be paused until the package as a whole can be agreed upon. As a matter of principle, such package approach has benefits: there are often practical connections between different reform proposals (for example, on return and border procedures); on other matters, compromises require a give-and-take in the mutual interest (for instance, solidarity in return for measures against secondary movements); linking different dossiers increases the room for compromise formulae, thus facilitating the resolution of the most protracted disputes by means of comprehensive deals.

At the same time, the package approach can result in never-ending debates and prevent the adoption of measures on which a political compromise exists already. As a political practice, it is not legally binding and could be overcome at any time provided a sufficient number of Member States in the Council supports the 'unbundling' of package deals. ${ }^{22}$ Negotiations on the 2016 reform package were allegedly close to such 'mini-deals' on the Asylum Agency and selected other instruments during $2018 / 19$, even though the adoption of these measures ultimately failed to muster sufficient political support. Successive Council Presidencies and the Commission pursued a similar strategy during 2021 and 2022: EU institutions reached a political agreement on the reform of the Asylum Agency (excluding those measures that are closely connected to the Pact), which was formally adopted by the Justice and Home Affairs Council at its meeting in December 2021; Eurodac reform was on the table, even though a majority of the Member States seemed to oppose the isolated adoption; moreover, the Screening Regulation and the Resettlement Framework Regulation were mentioned as potential 'mini-deals'. ${ }^{23}$ At the time of writing, none of these measures had formally been adopted, but the hope for trust-building by means of a step-by-step approach remained intact.

Core aspects of asylum reform, such as border procedures, solidarity, secondary movements, and asylum jurisdiction, will almost inevitably require a comprehensive reform package, which will ultimately have to be agreed upon at the highest political level. Heads of state or government may grasp how important asylum reform can be for the European project, and they are the appropriate forum for cross-sectoral compromise-building

22 See also ECJ, Istanbul Convention, Opinion 1/19, EU:C:2021:832, paras 229-274 in the context of international treaties where the Council waits (voluntarily) until all national parliaments have ratified a treaty.

23 See Commission, 'Report on Migration and Asylum' (n 3) 15. 
that connects asylum policy to other subject matters. ${ }^{24}$ Nevertheless, it remains a question of diplomatic finesse to identify a window of opportunity for such grand compromise. Raising the matter to the European Council too quickly entails the risk of failure and hardening cleavages.

Finally, opposition of reticent Member States may be overcome by means of qualified majority voting in the Council. ${ }^{25}$ Yet, we should be careful not to overestimate the potential of majority voting for three inter-related reasons. Firstly, deliberations in the Council and preparatory bodies are defined by an entrenched consensus culture. Conflictual voting rarely happens; negotiations habitually strive to take everyone on board. ${ }^{26}$ Secondly, the prevalence of compromise-building does not mean, crucially, that qualified majority voting is practically irrelevant. Empirical studies demonstrate that the behaviour of national representatives changes when they cannot simply block decisions by means of a veto; the 'shadow of the vote' renders negotiating positions more flexible. ${ }^{27}$ Thirdly, not all majority votes have the same bearing; governments may accept the final outcome even though they formally voted against an initiative (sometimes to demonstrate opposition to the domestic audience). Important asylum legislation may well be adopted by majority vote, but the degree of opposition and cleavage behind the vote matters.

Indeed, the ongoing constitutional conflict on the independence of the judiciary between, on the one side, the Commission and the Court of Justice and, on the other side, the Polish government and the Polish Constitutional Court exemplifies that constitutional conflicts are a risky undertaking. Do we really expect Hungary, Poland, and other Member States to grudgingly accept mandatory relocation adopted against their principled opposition by a majority in the Council? Of course, the Commission could press ahead with infringement proceedings and ask judges to authorise lump sums or penalty payments against Member States flatly refusing to comply with asylum legislation. ${ }^{28}$ Such pressure is an indispensable means

24 Note that discussion of the asylum dossier by the European Council does not entail that the majority requirements change; see ECJ, Slovak Republic \& Hungary $v$ Council, C-643/15 \& C-647/15, EU:C:2017:631, paras 143-150.

25 On the ordinary legislative procedure, see Articles 78(2), 294 TFEU.

26 See Fiona Hayes-Renshaw, 'The Council of Ministers: Conflict, Consensus, and Continuity' in Dermot Hodson and John Peterson (eds), Institutions of the European Union (4th edn, OUP 2017) ch 4.

27 See Jonathan Golub, 'In the Shadow of the Vote? Decision Making in the European Community' (1999) 53 International Organization 733-764.

28 See Articles 258, 260 TFEU. 
of law enforcement, also in the field of migration (as highlighted by the application for penalty payments against Hungary for disrespecting Court judgments on transit zones). Nevertheless, it can be risky to escalate tensions to the point of open conflict. The Hungarian Constitutional Court has shied away from openly confronting the Court of Justice on migratory matters for the moment, ${ }^{29}$ but the potential of conflict remains real: between courts and with regard to the Hungarian and Polish government.

It can be an expression of political wisdom not to force a constitutional conflict EU institutions might not win, also considering that populist governments eagerly exploit migration to spur anti-European sentiment among the population..$^{30}$ To prevent such an escalation may be the logic behind the consensus culture and the inbuilt pressure to agree on a compromise. Doing so promotes compliance with legal obligations and ultimately prevents the Union from falling apart. As stated previously, none of this prevents recourse to majority voting in scenarios where the degree of political tensions remains manageable. Even in such scenarios, however, it is no foregone conclusion that a sufficient number of Member States is willing to actively support a compromise. ${ }^{31}$ On many dossiers, there might quite simply not be a sufficient number of governments willing to vote 'yes'. Remember that many hide behind the principled opposition of the V4.

\section{5. 'Screening Light': Hardly a Novelty}

The remainder of this introductory contribution will discuss five themes, which highlight selected elements of the 'Pact'. Our assessment concentrates on those aspects of the legislative proposals that allow us to provide preliminary answers to the overarching enquiries presented at the outset. In doing so, our description follows the usual chronology of how instru-

29 See Hungarian Constitutional Court, decision of 10 December 2021, X/477/2021, $<$ http://hunconcourt.hu/announcement/decision-of-the-constitutional-court-on-t he-interpretation-of-the-provisions-of-the-fundamental-law-allowing-the-joint-ex ercise-of-powers $>$ accessed 15 December 2021; and Nóra Chronowski and Attila Vincze, 'Full Steam Back' (Verfassungsblog, 15 December 2021) <https://verfassun gsblog.de/full-steam-back/> accessed 15 December 2021.

30 See Daniel Thym, "The "Refugee Crisis" as a Challenge of Legal Design and Institutional Legitimacy’ (2016) 53 CML Rev. 1545, 1567-1572.

31 Majority voting requires, in accordance with Article 16(3) TEU, an active vote in favour of $55 \%$ of the Member States (i.e. 15 out of 26, with Denmark not participating as a result of the opt-out), which represent $65 \%$ of the population. 
ments are being applied in practice, from screening and border procedures to relocation and return. A decisive novelty, on which the Commission put much emphasis was the introduction, 'for the first time'32, of pre-entry screening of anyone apprehended in the context of an unauthorised border crossing, or after search and rescue. The novelty factor is underlined by the proposal of a new instrument: the Screening Regulation. ${ }^{33}$

Closer inspection of the Proposal for a Screening Regulation demonstrates the limited novelty factor. Mandatory elements under Article 6(6) correspond by and large to what border authorities are obliged to perform already under the Schengen Borders Code, the Eurodac Regulation, or when registering an asylum application-with the exception of a health screening, which most countries introduced in response to the COVID-19 pandemic. The timeframe for the screening of five to ten days mirrors today's prescription for the registration of asylum applications. ${ }^{34}$ Screening is a smart new label but has little added value in practice.

An example illustrates this point. Screening would support fast asylum procedures if it helped clarify the identity of individuals. However, Article 10 concentrates on checking biometric and other information with existing databases. Reference to 'data or information provided by or obtained from the third-country national concerned' ${ }^{35}$ could possibly be read to require Member States to explore information on smartphones or to use software identifying the dialect spoken (both tools are used, amongst others, by the German Federal Migration and Asylum Office). Yet, the reference is so vague that it can hardly be interpreted to mandate such intense-and controversial-methods. Tellingly, the 'standard debriefing form' in the annex refers to an 'initial indication' of nationality. Screening would not be much more than initial registration and an identification attempt.

The debriefing form does not constitute a formal decision subject to legal remedies; instead, screening is designed to prepare decision-making. Depending on the individual case, formal decisions will take the form of an asylum procedure under the Asylum Procedures Directive 2013/32/EU (including border procedures and special rules for vulnerable groups, whenever applicable), refusal of entry in line with the Schengen Borders Code Regulation (EU) 2016/399, or a return decision in accordance with

32 Commission Press Release (n 4).

33 Commission Proposal for a Screening Regulation, $\operatorname{COM}(2020) 612$ of 23 September 2020.

34 See Article 6(1), (7) Asylum Procedures Directive 2013/32/EU.

35 Ibid Article 10(1)(b). 
the Return Directive 2008/115/EC. Previous case law indicates that the legislature may establish such intermediary procedural steps provided that the initial conclusions can be challenged at a later stage in the context of legal remedies against the administrative decision that follows. ${ }^{36}$

A number of lacunae in the Commission Proposal could have negative repercussions on the rights of migrants and refugees, as Lyra Jakulevičienè will discuss in more detail in her chapter in this volume. Screening shall take place on the national territory but before the formal authorisation of entry (fiction of non-entry), ${ }^{37}$ thus implicitly asking Member States to restrict movement within the territory. Nevertheless, there are no explicit provisions on restrictions of mobility-or even detention-besides a vague reference to national laws in Recital 12 . While not any restriction on mobility amounts to detention, as we shall see, it is astonishing that the Commission refrains from proposing common standards. What is more, the Proposal remains unclear how the screening exercise would interact with asylum legislation, in particular, whether reception conditions and procedural guarantees under the Asylum Procedures Directive would start applying, in case of an asylum application, before or after the screening.

\section{Agencies: Refraining from 'More Europe'}

Lacunae in the Proposal for a Screening Regulation are a first indication that the Commission deliberately leaves Member States legislative and practical leeway on crucial matters. Doing so might be a matter of political strategy: EU institutions circumvent divisive political negotiations, thus facilitating the adoption of the proposals; moreover, they could wash their hands of responsibility for restrictive national laws and practices later. After all, it would remain the choice of national parliaments on how to design implementing legislation. That is not to say, crucially, that the Commission is unaware of the potential of wrongdoing. It proposes a monitoring mechanism, to be established at the national level, to ensure compliance with domestic and supranational legislation, including fundamental rights, 'in relation to the screening' (not, however, for border pro-

36 See ECJ, Samba Diouf, C-69/10, EU:C:2011:524, paras 40-44, 54, 57ff; and, by way of example, Article 17(2) Asylum Procedures Directive 2013/32/EU.

37 Article 4 Proposal for a Screening Regulation (n 33). 
cedures, return, or the like). ${ }^{38}$ We are left with an astonishing combination of European intervention and enhanced national responsibilities.

Our conclusion about the timid Europeanisation is reinforced by a comparison of the Pact with the non-paper of the incoming German Presidency, published one year before the Pact. ${ }^{39}$ In the non-paper, the German government had put much emphasis on an 'initial assessment' of asylum claims at the external borders, to be followed by rejection in case of manifestly unfounded or inadmissible applications and, possibly, relocation for those with a high likelihood of success. By contrast, the Commission's Proposal for a Screening Regulation does not prejudge the outcome of the asylum procedure. A debriefing form is to 'point to' any elements that might possibly influence the choice of procedure, and the decision whether or not to relocate someone is taken elsewhere. ${ }^{40}$ In essence, screening would not be much more than a reinforced border check and asylum registration.

A comparison with the non-paper demonstrates another reform step the Commission does not dare to go. The incoming German Presidency had pondered autonomous decision-making of the Asylum Agency and Frontex, which could possibly have conducted the pre-screening independently in a few years, after initially supporting 'frontline' Member States. Enhanced powers of the agencies did not find their way into the Screening Regulation, which, rather, entrusts the task to national authorities, with the support of the agencies acting 'within the[ir] mandate'41. However, the mandate of Frontex and the future Asylum Agency authorises support for host state decision-making only, on 'whose behalf' they may exceptionally be authorised to act. ${ }^{42}$ Doing so effectively codifies the practice in the hotspots, as Lilian Tsourdi will explain in her contribution on the operational powers of the agencies in this volume.

38 Ibid Article 7.

39 See German Government, 'Outline for Reorienting the Common European Asylum System' (Food for thought, 13 November 2019) <www.statewatch.org/medi a/documents/news/2019/dec/eu-asylum-FoodForThought-GermanNoPaper.pdf $>$ accessed 15 December 2021.

40 Article 14(2), (3) Proposal for a Screening Regulation (n 33).

41 Ibid Article 6(7).

42 See, for Frontex, Articles 43, 48(1)(b), (2), 82(4), (11) Frontex Regulation (EU) 2019/1896; and, for the future Asylum Office, Article 16a(2)(h) Amended Commission Proposal for an EUAA Regulation, $\operatorname{COM(2018)} 633$ of 12 September 2018 , read in combination with the political compromise enshrined in Council doc. $10555 / 17$ of 27 June 2017; note that to act 'on behalf of someone involves attribution of the agencies' conduct to the host state. 
At an intermediate level of abstraction, we may conclude that the Commission refrains from proposing an autonomous decision-making authority of the agencies, even in exceptional circumstances. Ultimate responsibility rests with domestic authorities. I am fully aware of the constitutional and practical challenges an autonomous decision-making power would entail. While Articles 77 and 78 TFEU can be read, in light of Court judgments, to embrace a competence for enhanced agency involvement, ${ }^{43}$ autonomous decision-making would be challenging for the Court architecture. Specialised tribunals under the responsibility of the European Union would have to be set up in the European periphery. ${ }^{44}$ That would take years and might pose myriad administrative difficulties, thus possibly discouraging the Commission from recommending 'more Europe' by means of greater agency involvement. What is more, doing so has the side-effect that the Commission can continue pointing to the primary responsibility of the Member States if something goes wrong on the ground.

Having said this, the agencies remain a crucial element in the EU's toolbox for asylum reform. Agency involvement will not bring about a brave new world of compliance single-handedly, but they are the best instrument we have to influence developments on the ground. Frontex and the future Asylum Agency can support domestic authorities and provide for fundamental rights oversight (Poland, for instance, rejected the deployment of Frontex at the border towards Belarus during 2021 partly because it scorned the presence of fundamental rights monitors). The substantial increase of the justice and home affairs budget under the Multiannual Financial Framework 2021-27, agreed upon in parallel to the Pact, will considerably extend the leverage of agencies, and the diverse funds can be used as an incentive to support the compliance of the Member States..$^{45}$ Iris Goldner Lang will focus on the financial aspects of asylum reform in her contribution.

43 See Roman Lehner, 'Rechtliche Möglichkeiten zur Schaffung einer EU-Asylbehörde' in Roman Lehner and Friederike Wapler (eds), Die herausgeforderte Rechtsordnung: Aktuelle Probleme der Asylpolitik (BWV 2018) 183-221; and Daniel Thym, 'Legal Framework for Entry and Border Controls' in Daniel Thym and Kay Hailbronner (eds), EU Immigration and Asylum Law. Article-by-Article Commentary (3rd edn, C.H. Beck/Hart/Nomos 2022), paras 7-8, 20a.

44 Cf Article 257 TFEU.

45 It may even serve as a leverage to incentivise change; at the time of writing during the autumn of 2021, the Commission was withholding funds from Greece until the government agreed to introduce a human rights monitoring mechanism. 


\section{Border Procedures: Administrative Bottleneck}

In contrast to screening, new rules on border procedures are a substantial novelty, demonstrating the significance of our overarching enquiry about 'the law is not enough'. On paper, a border procedure is a strict set of rules, which, nonetheless, embraces essential procedural guarantees, such as a personal interview and an individual assessment of each case, in line with Articles 11-13 Proposal for an Asylum Procedures Regulation of 2016, which the Pact leaves intact. ${ }^{46}$ The Amended Proposal of 2020 reaffirms the need for a legal remedy that 'shall provide for a full and ex nunc examination of both facts and points of law' ${ }^{47}$. Similarly, legal assistance shall be available to applicants at the external borders. ${ }^{48}$ Jens Vedsted-Hansen will zoom in on these procedural aspects in his contribution. The proposals on emergency measures for the benefit of Latvia, Lithuania and Poland in response to the instrumentalisation of migrants by Belarus demonstrate that the Commission continues to believe in the model of fast procedures with lesser standards in the border area. ${ }^{49}$

For our purposes, another element should be highlighted. Unfortunately, the guarantees in the Asylum Procedures Regulation are not always complied with in practice-in the same vein as the Reception Conditions Directive, in relation to which the Pact endorses the state of play of the negotiation on the 2016 Proposal. Lieneke Slingenberg will remind us of core aspects of that proposal. When it comes to non-compliance, ECtHR and ECJ judgments on the deficiencies of the Hungarian transit zones are telling examples: they found various deficits in terms of reception conditions, detention, and asylum procedure (judges were careful to assess each aspect individually, thus distinguishing different elements and not following each claim of illegality). ${ }^{50}$ Similarly, expedited procedures under Greek asylum legislation mostly do not qualify as border procedures for

46 See Proposal for an Asylum Procedures Regulation, $\operatorname{COM}(2016) 467$ of 13 July 2016.

47 Article 53(3) Amended Proposal for an Asylum Procedures Regulation (n 15).

48 Articles 14-17 Proposal for an Asylum Procedures Regulation (n 46).

49 See Article 2 Commission Proposal on provisional emergency measures (n 21); and Article 2 Commission Proposal addressing situations of instrumentalisation (n 21).

50 See ECtHR, judgment of 21 November 2019 [GC], No. 47287/15, Ilias \& Abmed $v$ Hungary; ECtHR, judgment of 2 March 2021, No. 36037/17, R.R. et al. v Hungary; ECJ, Országos Idegenrendészeti Fóigazgatóság Dél-alföldi Regionális Igazgatóság, C-924/19 PPU \& C-925/19 PPU, EU:C:2020:367; and ECJ, Commission v. Hungary, C-808/18, EU:C:2020:1029. 
the purposes of Union law, since they fall foul—in theory and practice-of essential procedural guarantees in the Directive 2013/32/EU. ${ }^{51}$

Flagrant compliance and implementation deficits concern not only the rights of migrants. The Commission insists that the border procedure, including legal remedies, should be completed within twelve weeks in regular circumstances and 20 weeks in times of crisis. ${ }^{52}$ To be sure, legislative amendments streamlining asylum procedures and shorter time-frames for legal oversight are meant to support compliance with these objectives. ${ }^{53}$ Limiting legal oversight to one level of appeal complies with human rights. ${ }^{54}$ In addition, new governance structures are meant to establish a permanent channel of communication between national governments and EU institutions. They may be a step in the right direction, although experience with the lacklustre performance of Schengen governance shows that the new governance mechanism might be sufficient to overcome structural compliance deficits. ${ }^{55}$ Remember that Article 31(3) Asylum Procedures Directive 2013/32/EU obliges Member States to complete asylum procedures within six months. State practice often fails to deliver, not only on the Greek islands. Thus, the Commission's insistence on efficiency may have the same fate as the rights of refugees and migrants: the law on books does not always translate into administrative practices on the ground.

Entrenched non-compliance is a problem in its own right, and it has a knock-on effect on the political negotiations: stakeholders lose faith in the law. ECRE is highly critical of the new proposals. ${ }^{56}$ Similarly, Mediterranean countries do not trust the time limits, while countries further North worry about continuous secondary movements. For that reason, ne-

51 Greek Council for Refugees, 'Fast-Track Border Procedure (Eastern Aegean Islands)' (AIDA/ECRE, 10 June 2021) <https://asylumineurope.org/reports/country /greece/asylum-procedure/procedures/fast-track-border-procedure-eastern-aegean> accessed 15 December 2021.

52 See Article 41 Amended Proposal for an Asylum Procedures Regulation (n 15); and Article 4(b) Proposal for a Crisis and Force Majeure Regulation, $\operatorname{COM}(2020)$ 613 of 23 September 2020.

53 See, in particular, Articles 35a, 41a, 53-54 Amended Proposal for an Asylum Procedures Regulation ( $\mathrm{n}$ 15); and the contribution by Jens Vedsted-Hansen to this volume.

54 Ibid Article 53(9); and ECJ, Samba Diouf (Fn. 36), para 69.

55 See Commission Recommendation (EU) 2020/1366 on a Migration Preparedness and Crisis Blueprint [2020] OJ C317/26, which applies immediately; and, for the future, Article 3-7 Proposal for an Asylum and Migration Management Regulation (n 14).

56 See the collection of comments \#HARDLY ROCKET SCIENCE $<$ https://hardlyro cketscience.org> accessed 15 December 2021. 
gotiations take place at two levels. On the one hand, governments discuss the letter of the law, and they are concerned, on the other hand, about practices on the ground. Such two-level game renders any negotiations terribly complex and are another reason for the absence of an agreement. States know that practices on the ground often differ from the law in the books.

\section{Accommodation: 'Closed' or 'Controlled' Centres?}

Notwithstanding the complexity of the legislative proposals, existing loopholes and ambiguities may cause confusion. A good example is the socalled 'fiction of non-entry', which the incoming German Presidency had proposed in its non-paper in line with an established category of German immigration laws. ${ }^{57}$ Such 'fiction of non-entry' can create confusion; it often equates with formal rightlessness, even though statutory and human rights guarantees can be invoked in transit zones in scenarios where the border crossing has not been formally authorised. What matters is not whether human rights and legislation apply before the authorisation of entry, rather what they prescribe in substance. Indeed, the 'fiction of nonentry' usually involves a lesser degree of protection on the basis of distinct legislative rules for these matters.

Absence of detailed explanations, in the Pact, reinforced uncertainties about what the "fiction of non-entry' entails for the rights of migrants during screening and border procedures. ${ }^{58}$ The most important uncertainty concerns detention, which the Commission does not recommend to use systematically during screening and border procedures. Detention would, also in future, not be automatic; it requires an individualised decision subject to a legal remedy. ${ }^{59}$ Recognising border procedures as a ground for detention does not support a different outcome, since any activation

57 See German Government (n 39); and Section 13(2) Residence Act (Aufenthaltsgesetz) <www.gesetze-im-internet.de/aufenthg_2004/_13.html> accessed 15 December 2021; see also Daniel Thym, 'Für ein "Helsinki" im deutschen Migrationsrechtsdiskurs' (Verfassungsblog, 10 July 2018) <https://verfassungsblog.de/f uer-ein-helsinki-im-deutschen-migrationsrechtsdiskurs $>$ accessed 15 December 2021.

58 See the general reference in Article 4 Proposal for a Screening Regulation (n 33); and Article 41(6) Amended Proposal for an Asylum Procedures Regulation (n 15).

59 See Articles 41(9)(d), 41a(5), (6) Amended Proposal for an Asylum Procedures Regulation (n 15). 
of this option would still require an individualised assessment, including inspection of alternatives to detention. ${ }^{60}$ These rules reiterate the contents of a Court judgment on detention in transit zones, which was based on existing legislation and could be overturned by means of a legislative amendment as a result. ${ }^{61}$ Yet, the Commission does not propose such fundamental reversal. ${ }^{62}$ Statutory rules on detention during asylum procedures will remain intact, even though detention for return purposes shall be facilitated, as Galina Cornelisse will reflect on in-depth.

This leaves us with an essential query: what is the difference between 'detention', subject to a tight legislative framework, and the 'fiction of non-entry', on which the Commission remains surprisingly nebulous? Arguably, the legal notion of detention provides some guidance. Not any 'restriction' of liberty, for instance in transit zones, will amount to 'deprivation' and 'detention'. In line with settled case law, it has to be assessed in light of various factors when the 'non-admission' with the ensuing restriction of liberty turns into 'detention', for which the statutory guarantees in the Reception Conditions Directive require an individualised assessment. ${ }^{63}$ Against this background, the silence on the part of the Commission on the consequences of the 'fiction of non-entry' may be perceived as a strategic choice. It deliberately creates room for manoeuvre for Member States to exploit legal uncertainties by means of strict practices on the ground. The end result may mirror the ambiguous preference for 'controlled' (not: 'closed') centres, the European Council had called for in June 2018. ${ }^{64}$

60 Article 8(2), (3)(c), (4) Reception Conditions Directive 2013/33/EU are not altered substantially by the Commission Proposal for a Reception Conditions Directive, $\operatorname{COM}(2016) 465$ of 13 July 2016.

61 See ECJ, Országos Idegenrendészeti Fóigazgatóság Dél-alföldi Regionális Igazgatóság (n 50), paras 238-239 and 257-259.

62 On the room for manoeuvre under human rights law, see Jürgen Bast, Frederik von Harbou and Janna Wessels, Human Rights Challenges to European Migration Policy: The REMAP Study (Nomos 2021) ch 2; and Daniel Thym, 'Expert Opinion on the Reform of the Common European Asylum System for the German Federal Ministry of the Interior' (January 2017) 41-44<https://papers.ssrn.com/sol3/papers .cfm?abstract_id=3163014> accessed 15 December 2021.

63 See ECtHR, Ilias \& Abmed v Hungary (n 50), paras 211-249; and ECJ, Országos Idegenrendészeti Fóigazgatóság Dél-alföldi Regionális Igazgatóság (n 50), paras 204-248.

64 European Council, Conclusions, EUCO 9/18 of 28 June 2018, para 6. 


\section{Hotspots Reloaded: Another Moria?}

A few weeks before the Commission presented the Pact, a devastating fire destroyed the Moria camp on the Greek island of Lesvos, which had become an epitome for the failure of the European Union to deliver fair and efficient asylum procedures, appropriate reception conditions, and reasonably effective return policies at the external borders. ${ }^{65}$ 'No more Morias' became a rallying cry for activists criticising EU asylum policy. It similarly continues to preoccupy the minds of officials in the Mediterranean countries who are concerned that the practical implementation of the Commission's policy blueprint would effectively result in huge camps at the external borders with protracted limbo situations. Asylum procedures might last longer than 12 to 20 weeks, countries of origin or transit often refuse to take back those without protection needs, and beneficiaries of international protection might not be resettled to other Member States. As a result, many small Morias might emerge.

Several legislative proposals are meant to prevent such overcrowding. Surprisingly, the Commission re-erected a concept that was among the very first legislative instruments on asylum to be adopted in the early 2000 s, only to be ignored in the institutional practice thereafter. ${ }^{66}$ The Temporary Protection Directive 2001/51/EC is to be officially repealed, and the Commission proposes to replace the instrument with a novel form of 'immediate protection'. ${ }^{67}$ Immediate protection status is designed for those fleeing civil war and is meant to suspend asylum procedures for one year, thereby safeguarding precious administrative resources. Meltem İneli Ciğer will introduce us to this genuine novelty factor and discuss uncertainties regarding the scope and implications of this innovative proposal for 'immediate protection'.

Crucial additional elements to prevent overcrowding will be procedural restrictions mentioned previously, the effectiveness of return, and relocation. When it comes to return, Madalina Bianca Moraru, Elspeth Guild, and Paula García Andrade will explore the pitfalls of the legislative proposals and of ongoing cooperation with third states. With regard to relocation, Francesco Maiani will discuss the merits and limitations of the

65 See 'Moria migrants: Fire destroys Greek camp leaving 13,000 without shelter' (BBC.com, 9 September 2021) <www.bbc.com/news/world-europe-54082201> accessed 15 December 2021.

66 See Meltem Ineli-Ciger, 'Time to Activate the Temporary Protection Directive' (2016) 18 EJML 1, 13-32.

67 See Article 11 Proposal for a Crisis and Force Majeure Regulation (n 52). 
rather lacklustre solidarity mechanism in detail. He will show that the rules are extremely complex and would require permanent negotiations among the Member States about different forms of 'flexible' solidarity ranging from relocation over administrative support to so-called return sponsorships. ${ }^{68}$ Search and rescue plays a critical role in many of these discussions; the Commission proposes a specific — and stronger-solidarity mechanism after disembarkation, although it might not survive the negotiations. ${ }^{69}$ Moreover, measures on rescue operations and the criminalisation of private actors remain decidedly vague. Violeta Moreno-Lax will assess these diverse initiatives in her comments on search and rescue.

Somewhat ironically, the novel 'return sponsorship', which received much criticism, may eventually result in relocation if the sponsoring country fails to realise return within eight months, or four months in times of crises. ${ }^{70}$ The Visegrád countries will scrutinise these rules carefully, in the same vein as the Mediterranean states will argue vehemently that the first entry rule is abandoned (something the Commission did not propose, unlike in the 2016 Proposal for a Dublin IV Regulation)..$^{71}$ The flipside of the-largely unchanged-continuation of the Dublin criteria on asylum jurisdiction concerns the survival of the transfer of jurisdiction in cases of secondary movements, which the Pact essentially retains, subject to some limitations (again, in contrast to the 2016 Proposal). ${ }^{72}$ Daniel Thym will assess what these choices mean for secondary movements. Highlighting the lack of innovation on asylum jurisdiction brings our comments full circle. Closer inspection of the legislative small-print demonstrated an almost staggering combination of change and continuity, as well as numerous political, practical, and normative pitfalls. One can hardly be surprised that the institutions have failed to agree on a swift compromise on these matters.

68 See Articles 45-61 Proposal for an Asylum and Migration Management Regulation (n 14); and Articles 2-3 Proposal for a Crisis and Force Majeure Regulation (n 52); on the state of play of the negotiations among Member States, see Council doc. 10450/21 of 6 July 2021.

69 Ibid Articles 47-49.

70 Ibid Article 55(2); and Article 2(7) Proposal for a Crisis and Force Majeure Regulation (n 52).

71 Contrast ibid Article 21 to Commission Proposal for a Dublin IV Regulation, $\operatorname{COM}(2016) 270$ of 4 May 2016.

72 Contrast ibid, Articles 27(1), 35(1), (2) to Article 9a Proposal for a Dublin IV Regulation, as discussed among Member States according to Council doc. 8895/18 of 17 May 2018. 


\section{Conclusion: The Alternative is not the Status Quo}

It is sometimes said that the status quo might be better than a bad reform. From a purely legal-doctrinal perspective that is correct. If the Asylum Procedures Directive is not amended, it remains the law in the book and must be respected by domestic authorities as a matter of positive law. Having said this, failure of legislative reform might increase the appetite, among the Member States and the supranational institutions, for alternative policy responses, which complement or replace the need for legislative reform: externalisation is the most obvious alternative. Disagreement on how to deal with arrivals might result in their prevention by means of cooperation with third states. It's like the proverbial hot potato. Member States pass it around until it falls to the floor.

Those who do not want this to happen should accept that the only viable alternative to externalisation is a reasonably well-functioning Common European Asylum System, not a continuation of the status quo. The need for political compromise is even more warranted if we remember our introductory comments about 'the law is not enough'. Failure of legislative reform might result in gradual disintegration, with Member States taking supranational legislation less and less seriously. Read the signs of the wall. Greece has got away with inappropriate reception conditions for years; we all know the pushback allegations against Greece, Croatia, and Spain, as well as, more recently, Poland and Lithuania. Some-not necessarily allof these measures are illegal, and they continue nonetheless. We might see more of the same if asylum legislation was blocked indefinitely. Political will would gradually replace the doctrinal force of the law. ${ }^{73}$ That may be frustrating for legal academics, but it's better to face unpleasant news than to ignore it. Without a legislative reform which works reasonably well in practice, the European asylum system might go down the drain.

73 See generally Luisa Marin, 'Waiting (and Paying) for Godot: Analyzing the Systemic Consequences of the Solidarity Crisis in EU Asylum Law' (2020) 22 EJML 60-81; Thym, 'The "Refugee Crisis"' (n 30), 1554-58; and Evangelia (Lilian) Tsourdi, 'Asylum in the EU: One of the Many Faces of Rule of Law Back-sliding?' (2021) 17 European Constitutional Law Review 471-496. 